\title{
The role of p21 3'UTR gene polymorphism in the risk of prostate cancer: A pilot study
}

\author{
MONIKA KMEŤOVÁ SIVOŇOVÁ ${ }^{1}$, MARTA VILČKOVÁ ${ }^{1}$, JANA JUREČEKOVÁ ${ }^{1}$, \\ JOZEF HATOK $^{1}$, DUŠAN DOBROTA ${ }^{1}$, RÓBERT DUŠENKA ${ }^{1,2}$ and JÁN KLIMENT ${ }^{2}$ \\ ${ }^{1}$ Department of Medical Biochemistry, Comenius University in Bratislava, Jessenius Faculty of Medicine; \\ ${ }^{2}$ Department of Urology, Comenius University in Bratislava, Jessenius Faculty of \\ Medicine and University Hospital of Martin, Martin, Slovak Republic
}

Received August 31, 2012; Accepted November 28, 2012

DOI: $10.3892 / \mathrm{mmr} .2012 .1242$

\begin{abstract}
The cell cycle regulator p21 plays an important role in regulating critical cell activities including cell cycle control, DNA repair and apoptosis. Consequently, it may affect the efficacy of the response to DNA damage and tumor development. The aim of our study was to evaluate the frequencies of the $p 21$ C70T polymorphism, the association between this genetic variant and smoking status, and the serum prostatespecific antigen (PSA) levels and Gleason score in 118 prostate cancer patients and 130 males routinely screened for prostate cancer in the Slovak population. Blood samples were collected from all individuals for DNA isolation, used for subsequent genotyping assays via PCR-RFLP methods. Overall, we did not observe any significant association between this polymorphism and prostate cancer risk. An analysis of the association between the $p 21$ genotypes and smoking was then conducted. Among smokers, $C C$ and $C T$ genotypes were associated with a non-significant increased risk (OR=1.48; 95\% CI, 0.80-2.76 and $\mathrm{OR}=1.15 ; 95 \% \mathrm{CI}, 0.27-4.77$, respectively; $\mathrm{p}>0.05$ ) in comparison to non-smokers with the $C C$ genotype. Patients with a $C T$ genotype and serum PSA levels $\geq 10 \mathrm{ng} / \mathrm{ml}$ had an $84 \%$ decrease in prostate cancer risk $(\mathrm{OR}=0.16 ; 95 \% \mathrm{CI}$, 0.03-0.75; $\mathrm{p}<0.05$ ) compared to cases with serum PSA levels $<10 \mathrm{ng} / \mathrm{ml}$ and the $C C$ genotype. No significant association was detected between Gleason score and prostate cancer risk. Based on these results, we concluded that the $p 21$ C70T polymorphism is associated with decreased risk of prostate cancer in Slovak men. To confirm these findings, a systematic approach is required to identify sequence variants in this and other related genes, and subsequently, to test for an association between such variants, smoking status and tumor-specific clinicopathological characteristics in large samples.
\end{abstract}

Correspondence to: Dr Monika Kmet'ová Sivoňová, Department of Medical Biochemistry, Jessenius Faculty of Medicine, Comenius University, Malá hora 4, 03601 Martin, Slovak Republic

E-mail: sivonova@jfmed.uniba.sk

Key words: p21, gene polymorphism, prostate cancer, cigarette smoking, Slovak population

\section{Introduction}

The etiology of prostate cancer is largely unknown, with the exception of a few known risk factors such as advancing age, intact-tight androgen metabolism, ethnicity and genetic background $(1,2)$. For the maintenance of prostate growth, the complex equilibrium between cell growth, proliferation and apoptosis-inducing factors is essential and fluctuations in this balance may lead to tumorigenesis and cancer. In prostate cancer progression, loss or suppression of apoptosis has been heavily implicated. Apoptosis induction is considered an effective therapeutic approach for the treatment of prostate tumors (3).

Investigations into the role of cell cycle regulatory molecules in the induction of apoptosis in cancer have provided a better understanding of the biology of cancer cells. Cell cycle control is crucial for normal cell growth and differentiation and is regulated by cyclin-dependent kinases (CDKs). Activity of CDKs is suppressed by CDK inhibitors. A universal inhibitor of cyclin-dependent kinases (CDK2, CDK3, CDK4, and CDK6) is p21, also known as CDKN1A, WAF1, CAP20, Cip1 and Sdi1 (4). Cell cycle inhibitory effects of p21 may be attributed, not only to its ability to bind CDKs, but also to its binding to proliferating cell nuclear antigen (PCNA), resulting in inhibition of cell cycle progression in either G1 and G2, or in the S-phase (5). This protein also has other important functions including the regulation of apoptosis. When cells are exposed to genotoxic agents, $\mathrm{p} 53$ protein is activated via phosphorylation and binds to $\mathrm{p} 53$-responsive elements of the p21 gene (6). p21 was initially discovered as a p53-target gene, but has since been suggested to play a role as a downstream effector of other tumor suppressors, including BRCA1, TGF- $\beta$ and Wnt-1 (5,7). Although activation of p21 is crucial in mediating p53-dependent cell growth arrest, it is not essential for p53-mediated apoptosis, as suggested by the fact that p53 is able to induce apoptosis in cells lacking p21 (8). p21 has a dual role, and in addition, can assume both pro- or anti-apoptotic functions in response to anti-tumor agents, depending on the cell type and context $(5,9)$.

The gene for p21 is localized on chromosome 6p21.2. It consists of three exons and two introns and encodes a $21-\mathrm{kDa}$ protein. The translation region lies mainly in exon 2 (10). Mutations or single nucleotide polymorphisms (SNPs) in the 
p21 gene may result in alteration of p21 expression and/or activity, thereby modulating susceptibility to cancer (11-13). A total of 40 SNPs have been identified in the $p 21$ gene and their frequency depends on ethnicity and geography. From these SNPs, 35 are intronic, 7 have an allele frequency $>10 \%$ $(\sim 1.3 \mathrm{~kb}$ upstream of exon 2$)$ and 4 are detected within the 3' untranslated region (3'UTR). The most commonly studied polymorphism of $p 21$ is Ser31 Arg. A substitution of $\mathrm{C}$ to A in the third base of codon 31 of p21 ( $p 21 C 98 A$, rs1801270) results in a serine to arginine amino acid substitution in the DNA-binding zinc finger motif of the protein (14). Only one of the SNPs within the 3'UTR, p21 C70T (rs1059234), has an allele frequency $>10 \%$ and causes a single $\mathrm{C}$ to $\mathrm{T}$ substitution 20 nucleotides downstream of the stop codon at exon 3 . Therefore, $p 21 C 98 A$ and $p 21 C 70 T$ are thought to alter p21 function (15).

These $p 21$ SNPs have been associated with a range of human cancers in various populations $(14,16-20)$. We have found four other studies (21-24) in connection with prostate cancer and $p 21$ genetic variation, but only one of these studies has focused on the $p 21 C 70 T$ polymorphism and prostate cancer (24).

The present pilot study is therefore the first to investigate the correlation between DNA variants within the 3'UTR of the $p 21$ gene ( $p 21$ C $70 T)$ and susceptibility to prostate cancer within the Slovak population. The study also attempted to establish a potential association of these gene variations with smoking status and tumor-specific clinicopathological characteristics or serum prostate-specific antigen (PSA) levels and Gleason score.

\section{Materials and methods}

Study subjects and samples. This study included 118 newly diagnosed prostate cancer patients and 130 healthy controls under the age of 50. Patients were recruited between May 2009 and December 2011 at the Department of Urology when undergoing regular prostate cancer screening. Final diagnoses of cases were confirmed by routine histopathological examination. Control subjects were cancer-free individuals randomly selected from a cancer screening program for early detection of prostate cancer conducted in the same region during the period when the case patients were recruited. The selection criteria for the controls included absence of individual history of cancer, and controls were frequency matched to case patients based on age. Cases and controls were interviewed with regard to age, smoking status (i.e., habitual smokers and never-smokers), previous and/or current prostate disease, and history of incidence of cancer and other chronic diseases. The studied population is described in Table I. The present study was approved by the Ethics Board of Jessenius Faculty of Medicine, Comenius University, and written informed consent was obtained from all individuals prior to inclusion in the study.

DNA isolation. Peripheral venous blood was collected in $2 \mathrm{ml}$ heparinized tubes and the specimens were immediately stored at $-20^{\circ} \mathrm{C}$ for genotyping. In cases and controls, genomic DNA was isolated from peripheral leukocytes by proteinase $\mathrm{K}$ digestion, phenol/chloroform extraction and ethanol precipita-
Table I. Principal characteristics of the control and prostate cancer patient groups.

\begin{tabular}{lcc}
\hline Characteristics & $\begin{array}{c}\text { Controls (n=130) } \\
\mathrm{n}(\%)\end{array}$ & $\begin{array}{c}\text { Cases }(\mathrm{n}=118) \\
\mathrm{n}(\%)\end{array}$ \\
\hline $\begin{array}{l}\text { Age in years (median, range) } \\
\text { Smoking status }\end{array}$ & $59(50-78)$ & $66(53-84)$ \\
$\quad$ Never smokers & $102(78.5)$ & $83(70)$ \\
Smokers & $28(21.5)$ & $35(30)$ \\
Serum PSA at diagnosis & & \\
$<10 \mathrm{ng} / \mathrm{ml}$ & $130(100)$ & $53(45)$ \\
$\geq 10 \mathrm{ng} / \mathrm{ml}$ & 0 & $45(38)$ \\
Unknown & 0 & $20(17)$ \\
$\begin{array}{l}\text { Gleason score } \\
\text { grade } 1+2)\end{array}$ & & \\
$<7$ & & $33(28)$ \\
$\geq 7$ & N/A & $85(72)$ \\
\hline
\end{tabular}

PSA, prostate-specific antigen; N/A, not applicable.

tion before it was dissolved in TE buffer $(\mathrm{pH} 7.5)$ and stored at $-20^{\circ} \mathrm{C}$ until genotype analysis.

PCR assay for p21 C70T genotyping. The p21 C70T polymorphism was determined by PCR-RFLP as described by Taghavi et al (16). Briefly, the amplification reactions were carried out in a $25 \mu \mathrm{l}$ volume consisting of $100 \mathrm{ng}$ genomic DNA, $25 \mathrm{pmol}$ of each primer (forward: 5'-CCCAGGGAAGGGTGTCCTG-3' and reverse: 5'-GGGCGGCCAGGGTATGTAC-3'), $200 \mu \mathrm{mol} / 1$ deoxynucleoside triphosphates and 1 unit of Taq polymerase in 10X PCR buffer composed of $16.6 \mathrm{mmol} / 1\left(\mathrm{NH}_{4}\right)_{2} \mathrm{SO}_{4}$ and $20.0 \mathrm{mmol} / 1 \mathrm{MgCl}_{2}, \mathrm{pH}$ 8.8. The cycling conditions were $94^{\circ} \mathrm{C}$ for $5 \mathrm{~min}$, followed by 33 cycles at $95^{\circ} \mathrm{C}$ for $30 \mathrm{sec}, 61.5^{\circ} \mathrm{C}$ for $30 \mathrm{sec}$, and $72^{\circ} \mathrm{C}$ for $30 \mathrm{sec}$ with a final cycle at $72^{\circ} \mathrm{C}$ for $5 \mathrm{~min}$. A $10 \mu \mathrm{l}$ aliquot of the appropriate PCR product was digested with 2 units of the restriction enzyme Pst I (Fermentas Co., Denmark) at $37^{\circ} \mathrm{C}$ for $30 \mathrm{~min}$ and separated on ethidium bromide-stained 3\% agarose gel. The intact Pst I site (in the wild-type allele) generated two 126 and $173 \mathrm{bp}$ fragments. The loss of the PstI site (C to T polymorphism) yielded a $298 \mathrm{bp}$ fragment (Fig. 1). Genotypes were verified by repeating PCR-RFLP on 40 random samples.

Statistical analysis. Genotype frequencies for the p21 C70T polymorphism were calculated for the prostate cancer patient and healthy control groups. Comparisons of genotype distribution and its association with prostate cancer susceptibility, smoking status and clinical data were performed using the Chi-square test with all odds ratio (OR) values being adjusted for age, which is considered to be a confounder. Statistical analysis was performed using StatsDirect statistical package version 2.7.8 (http://www.statsdirect.com). Quantitative variables including age and smoking status were compared by the Student's t-test. All P-values cited were two-sided and $\mathrm{P}<0.05$ was considered statistically significant. 


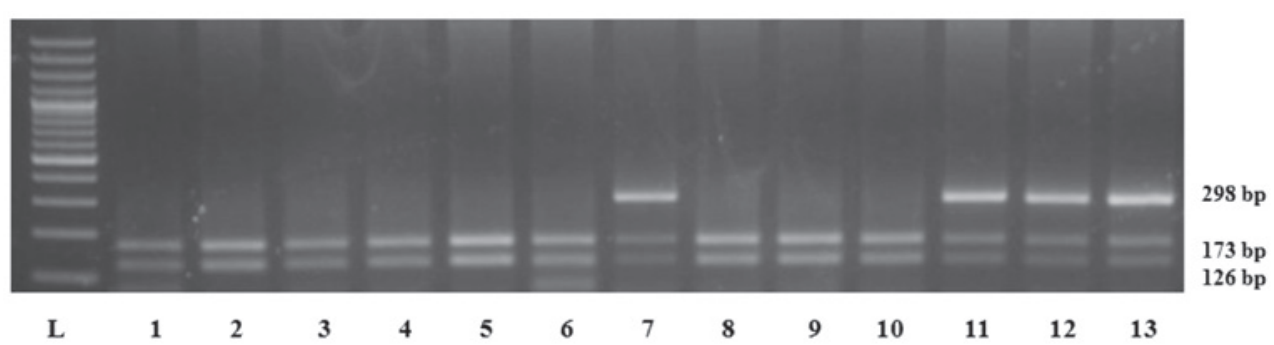

Figure 1. The PCR-RFLP analysis of the $p 21$ C70T polymorphism. Ethidium bromide-stained electrophoresed representative PCR-RFLP product samples: 100 bp ladder (lane L); $C C$ allele (lanes 1-6; 8-10) and $C T$ allele (lanes 7; 11-13).

Table II. Distribution of the $p 21$ C70T polymorphism.

\begin{tabular}{lrrlc}
\hline Genotypes & $\begin{array}{c}\text { Controls } \\
\mathrm{n}(\%)\end{array}$ & $\begin{array}{c}\text { Cases } \\
\mathrm{n}(\%)\end{array}$ & OR (95\% CI) & P-value \\
\hline$C C$ & $108(83)$ & $104(88)$ & $1.00($ ref.) & - \\
$C T$ & $22(17)$ & $14(12)$ & $0.66(0.32-1.36)$ & NS \\
\hline
\end{tabular}

Odds ratio (OR) adjusted for age. NS, not significant.

Table III. Risk of prostate cancer associated with p21 C70T genotypes and cigarette smoking in cases and controls.

\begin{tabular}{lcc}
\hline Genotype & Never-smokers $^{\mathrm{a}}$ & Smokers $^{\mathrm{a}}$ \\
\hline$C C$ & $73 / 84$ & $31 / 24$ \\
OR $(95 \% \mathrm{CI})$ & 1.00 (ref.) & $1.48(0.80-2.76)$ \\
$C T$ & $10 / 18$ & $4 / 4$ \\
OR $(95 \% \mathrm{CI})$ & $0.64(0.27-1.47)$ & $1.15(0.27-4.77)$ \\
\hline
\end{tabular}

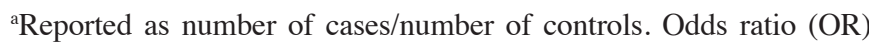
adjusted for age.

\section{Results}

General characteristics of cases and controls. The frequency distribution of the general characteristics of the 118 prostate cancer patients and 130 controls is shown in Table I. A significant difference was observed between cases and controls in age and serum PSA levels at the time of diagnosis $(\mathrm{p}<0.001)$. In the group of 118 patients, 33 patients $(28 \%)$ had a Gleason score $<7$ and the remaining 85 patients $(72 \%)$ had a Gleason score $\geq 7$. More smokers were observed among cases than among controls (30 vs. $21.5 \%$ ).

Genotype frequencies of $p 21$ C70T polymorphism. The genotype frequencies of the $p 21$ C70T polymorphism are shown in Table II. The distribution of $p 21$ C70T genotypes in either group was in agreement with the Hardy-Weinberg equilibrium ( $\mathrm{p}>0.05$; data not shown). The $C C$ and $C T$ genotype frequencies were 88 and $12 \%$ among cases and 83 and $17 \%$ among controls, respectively. No TT genotype was observed in this polymorphism. The $p 21 C T$ genotype was associated with decreased risk for the development of prostate cancer
Table IV. Association of $p 21$ C70T polymorphism with serum PSA and Gleason score in prostate cancer patients $(n=118)$.

\begin{tabular}{lcc}
\hline & \multicolumn{2}{c}{$p 21 C 70 T$} \\
\cline { 2 - 3 } & $\begin{array}{c}C C \\
\mathrm{n}(\%)\end{array}$ & $\begin{array}{c}C T \\
\mathrm{n}(\%)\end{array}$ \\
\hline $\begin{array}{l}\text { Total prostate cancer, } \mathrm{n}(\%) \\
\text { Serum PSA at diagnosis }\end{array}$ & $104(88)$ & $14(12)$ \\
$<10 \mathrm{ng} / \mathrm{ml}$ & $41(77.4)$ & $12(22.6)$ \\
$\geq 10 \mathrm{ng} / \mathrm{ml}$ & $43(95.5)$ & $2(4.5)$ \\
OR $(95 \% \mathrm{CI})$ & 1.00 & $0.16(0.03-0.75)$ \\
P-value & - & 0.02 \\
Gleason score & & \\
$<7$ & $30(91)$ & $3(9)$ \\
$\geq 7$ & $74(87)$ & $11(13)$ \\
OR (95\% CI) & 1.00 & $1.48(0.39-5.71)$ \\
P-value & - & $\mathrm{NS}$ \\
\hline
\end{tabular}

Odds ratio (OR) adjusted for age. NS, not significant; PSA, prostatespecific antigen.

$(\mathrm{OR}=0.66 ; 95 \% \mathrm{CI}, 0.32-1.36 ; \mathrm{p}>0.05)$ compared with the CC genotype.

Smoking status in cases and controls. The smoking status (never and ever smokers) in cases and controls was also analyzed with respect to its association with genotypes (Table III). Smokers with the $p 21$ C70T common genotype (CC) or heterozygous mutant $(C T)$ genotype were positively associated with prostate cancer risk $(\mathrm{OR}=1.48 ; 95 \% \mathrm{CI}, 0.80-2.76$ and $\mathrm{OR}=1.15 ; 95 \%$ CI, 0.27-4.77, respectively; $>0.05$ ). The presence of the $C T$ genotype in never-smokers was associated with decreased prostate cancer risk (OR=0.64; 95\% CI, 0.27-1.47).

Serum PSA levels and Gleason score in prostate cancer patients. The association of the $p 21 C 70 T$ genotypes with serum PSA levels and Gleason score in 118 prostate cancer patients was analyzed (Table IV). Cases with serum PSA levels $\geq 10 \mathrm{ng} /$ $\mathrm{ml}$ and the $C T$ genotype tended to have significantly decreased prostate cancer risk $(\mathrm{OR}=0.16 ; 95 \% \mathrm{CI}, 0.03-0.75 ; \mathrm{p}>0.05)$ in comparison to cases with serum PSA levels $<10 \mathrm{ng} / \mathrm{ml}$ and the $C C$ genotype. The OR for high-grade (Gleason score $\geq 7$ ) versus 
low-grade (Gleason score <7) disease was 1.48 (95\% CI 0.395.71) for the $C T$ genotype relative to the $C C$ genotype.

\section{Discussion}

Cell cycle deregulation is common in human cancer, and alteration of $\mathrm{p} 21$, the critical cell cycle regulator, is involved in the development of a number of human malignancies $(9,17)$. The $p 21$ C70T polymorphism is thought to cause a functional change in $\mathrm{p} 21$, and as this polymorphism lies in a crucial region for cell differentiation, proliferation may increase cancer risk by altering messenger RNA stability, which, in turn, may affect protein expression and activity $(25,26)$. Certain studies suggest that this polymorphism has a functional significance and most likely contributes to genetic susceptibility to several types of cancer $(15,25)$. However, other studies have also demonstrated no association between polymorphisms and cancer risk $(16,27)$. A possible explanation for the discrepancies between these studies may be due to non-random sampling, limited sample size, different molecular mechanisms involved in carcinogenesis, ethnic disparity and/or linkage disequilibrium of this polymorphism with other functional variants at the susceptibility loci.

Our results suggest that the $p 21 C 70 T$ polymorphism may not be relevant as a risk factor for prostate cancer development due to a non-significant protective effect of the $p 21 C T$ polymorphic variant on prostate cancer risk. The prevalence rate of $C C$ homozygosity and $C T$ heterozygosity was 83 and $17 \%$, respectively, in our Caucasian control subjects. These frequencies are similar to the frequencies observed in other studies on p21 C70T polymorphism in identical populations $(15,24)$.

Only one case-control study by Kibel et al evaluated the association of the p21 C70T polymorphism with the risk of advanced prostate carcinoma in a European-American population (24). The authors of that study demonstrated that polymorphic genotypes $C T$ and $T T$ were associated with an increased risk of advanced prostate carcinoma compared with the $C C$ genotype $(\mathrm{OR}=2.24 ; 95 \% \mathrm{CI}, 1.02-4.95)$ and these genotypes were more strongly associated with more aggressive metastatic disease (androgen-independent disease or mortality from metastatic prostate carcinoma) $(\mathrm{OR}=2.88 ; 95 \%$ CI, 1.19-6.97).

To the best of our knowledge, this is the first study to examine the association of the $p 21$ C70T polymorphism, prostate cancer risk and smoking status. It is well known that differences in genetic background may not only affect the susceptibility of individuals to cancer, but may also modify the effects of environmental carcinogens $(16,28)$. In the present study, we have shown that smokers with the $p 21$ homozygote variant genotype $(C C)$ and heterozygous mutant $(C T)$ genotype exhibited higher prostate cancer risk, while non-smokers with the $C T$ genotype had a reduced risk. The finding of a greater risk in ever-smokers also suggests that the $p 21$ variant genotypes has an impact on cell cycle control induced by DNA damage caused by carcinogens in tobacco smoke (29). We hypothesized that the balance between cell cycle arrest and apoptosis may be shifted to cell cycle arrest and lead to more mutations and genomic instability in individuals heavily exposed to carcinogens, as cells with incompletely repaired genomes may not be removed by apoptosis.
Results of previous studies have demonstrated that $\mathrm{p} 21$ protein expression in prostate cancer is associated with poor clinical outcome following treatment for localized disease, such as radical prostatectomy or radiation therapy $(30,31)$. The immunohistochemical study of Omar et al showed that expression of the $\mathrm{p} 21$ protein did not correlate with patient age at diagnosis, pretreatment serum PSA, histologic grade and clinical stage (32). However, to the best of our knowledge, no study has previously evaluated the effect of the p21 C70T polymorphism on the serum PSA levels and Gleason score in prostate cancer patients. Compared to patients with the $C C$ genotype who had serum PSA levels $<10 \mathrm{ng} / \mathrm{ml}$, patients who were $C T$ genotype carriers and had serum PSA levels $\geq 10 \mathrm{ng} /$ $\mathrm{ml}$ had a significant 0.16 -fold decreased prostate cancer risk. Patients with a Gleason score $>7$ and the variant genotype $(C T)$ did not show a significantly higher risk compared to patients who carried wild-type genotype $(C C)$ and had a Gleason score $<7$. These findings suggest that the $p 21 C T$ genotype may be a protective factor for prostate cancer development, particularly for patients with a serum PSA level $>10 \mathrm{ng} / \mathrm{ml}$. The precise manner in which this polymorphism affects serum PSA levels and prostate cancer development, however, may require more detailed in vitro and in vivo studies.

It has been shown that the $p 21$ C70T polymorphism always occurs together with a more common $p 21$ polymorphism on codon 31 (p21 C98A) (15), however, no studies are currently available in connection with prostate cancer. There are three studies that have shown an association between the $p 21 \mathrm{C} 98 \mathrm{~A}$ polymorphism and prostate cancer development in various populations (21-23). Liu et al performed a meta-analysis of 33,120 cancer cases and 44,954 controls from 49 publications with 66 individual case-control studies for this polymorphism (14). The authors of that study demonstrated that the p21 31 Arg allele is a low-penetrant risk factor for cancer development, particularly among Caucasians. When stratifying by cancer types, significantly increased risks were observed for breast cancer and 'other cancers' among Caucasians and significantly decreased risks were observed for oesophageal and gastric cancer among Asians.

Therefore, we conclude the following: a) there was a decreased risk of prostate cancer with the $p 21 C T$ genotype and a protective effect of the $\mathrm{T}$ allele; $\mathrm{b}$ ) smokers carrying the $C C$ and $C T$ genotypes were at an increased risk of prostate cancer compared to non-smokers with the $C C$ genotype; c) a significantly decreased prostate cancer risk was observed in men with serum PSA levels $\geq 10 \mathrm{ng} / \mathrm{ml}$ and $p 21 C T$ genotype; and d) in a case analysis according to Gleason score, no significant trend in OR from the $C T$ towards the $C C$ genotype between low-grade versus high-grade disease was detected. A complete interpretation of our results is limited at present, as we concentrated on only one functionally active $p 21$ polymorphism. Due to the complexity with multiple genetic and environmental factors in the development of prostate cancer, large population studies are required that are able to take into account all variables including association with other polymorphisms in genes for DNA repair, cell cycle control and apoptosis systems, exposure to environmental factors, ethnic and demographic features. With this in mind, future studies are likely to concentrate on larger population sizes in order to validate any possible interactions and to be able to 
understand likely interactions and their relevance for prostate cancer development. Such studies should help to elucidate any impact and interaction of this polymorphism with other polymorphisms in the $p 21$ gene and cell cycle regulatory genes $(p 53, p 27)$ with overall respect to prostate cancer risk assessment.

\section{Acknowledgements}

This study was supported by the Ministry of Health of the Slovak Republic under the projects 2007/45-UK-10 'Genetic polymorphism of xenobiotic metabolising enzymes and susceptibility to prostate cancer in the Slovak population', MH SR 2007/57-UK-17 and by VEGA grant 1/426207. The study was also supported by the project 'Center of Excellence for Research on Personalized Therapy (CEVYPET)', code 2622012053, co-financed from EU sources and European Regional Development Fund. The authors are grateful to Dr N.A. Yeboah for critical reading of the manuscript and wish to thank Mrs. M. Martinčeková for her technical assistance.

\section{References}

1. Grönberg H: Prostate cancer epidemiology. Lancet 361: 859-864, 2003.

2. Sivonova MK, Dobrota D, Matakova T, et al: Microsomal epoxide hydrolase polymorphisms, cigarette smoking and prostate cancer risk in the Slovak population. Neoplasma 59: 79-84, 2012.

3. Khan N, Adhami VM and Mukhtar H: Apoptosis by dietary agents for prevention and treatment of prostate cancer. Endocr Relat Cancer 17: 39-52, 2010

4. Gartel AL and Tyner AL: The role of the cyclin-dependent kinase inhibitor p21 in apoptosis. Mol Cancer Ther 1: 639-649, 2002.

5. Liu S, Bishop WR and Liu M: Differential effects of cell cycle regulatory protein $\mathrm{p} 21$ (WAF1/Cip1) on apoptosis and sensitivity to cancer chemotherapy. Drug Resist Updat 6: 183-195, 2003.

6. Suzuki H, Ito R, Ikeda K and Tamura TA: TATA-binding protein (TBP)-like protein is required for $\mathrm{p} 53$-dependent transcriptional activation of an upstream promoter of the p21Waf1/Cip1 gene. J Biol Chem 282: 19792-19803, 2012.

7. Englert C, Maheswaran S, Garvin AJ, Kreidberg J and Haber DA Induction of p21 by the Wilms' tumor suppressor gene WT1. Cancer Res 57: 1429-1434, 1997.

8. Deng C, Zhang P, Harper JW, Elledge SJ and Leder P: Mice lacking p21CIP1/WAF1 undergo normal development, but are defective in G1 checkpoint control. Cell 82: 675-684, 1995.

9. Gartel AL: The conflicting roles of the cdk inhibitor p21(CIP1/ WAF1) in apoptosis. Leuk Res 29: 1237-1238, 2005.

10. El-Deiry WS, Tokino T, Velculescu VE, et al: WAF1, a potential mediator of p53 tumor suppression. Cell 75: 817-825, 1993.

11. Ma H, Zhou Z, Wei S and Wei Q: Association between $\mathrm{p} 21$ Ser31Arg polymorphism and cancer risk: a meta-analysis. Chin J Cancer 30: 254-263, 2011.

12. Gravina S, Lescai F, Hurteau G, et al: Identification of single nucleotide polymorphisms in the p21 (CDKN1A) gene and correlations with longevity in the Italian population. Aging (Albany NY) 1: 470-480, 2009.

13. Keshava C, Frye BL, Wolff MS, McCanlies EC and Weston A: Waf-1 (p21) and p53 polymorphisms in breast cancer. Cancer Epidemiol Biomarkers Prev 11: 127-130, 2002.
14. Liu F, Li B, Wei Y, et al: P21 codon 31 polymorphism associated with cancer among white people: evidence from a meta-analysis involving 78,074 subjects. Mutagenesis 26: 513-521, 2011.

15. Li G, Liu Z, Sturgis EM, et al: Genetic polymorphisms of p21 are associated with risk of squamous cell carcinoma of the head and neck. Carcinogenesis 26: 1596-1602, 2005.

16. Taghavi N, Biramijamal F, Abbaszadegan MR, Khademi H, Sotoudeh M and Khoshbakht S: P21(waf1/cip1) gene polymorphisms and possible interaction with cigarette smoking in esophageal squamous cell carcinoma in northeastern Iran: a preliminary study. Arch Iran Med 13: 235-242, 2010.

17. Lin G, Fang F, Yu XJ and Yu L: Meta-analysis of the relationship between p21 Ser31Arg polymorphism and lung cancer susceptibility. Genet Mol Res 10: 2449-2456, 2011.

18. Shirai O, Ohmiya N, Taguchi A, et al: P53, p21, and p73 gene polymorphisms in gastric carcinoma. Hepatogastroenterology 57: 1595-1601, 2010.

19. Ebner F, Schremmer-Danninger E and Rehbock J: The role of TP53 and p21 gene polymorphisms in breast cancer biology in a well specified and characterized German cohort. J Cancer Res Clin Oncol 136: 1369-1375, 2010.

20. Yang W, Qi Q, Zhang H, et al: p21 Waf1/Cip1 polymorphisms and risk of esophageal cancer. Ann Surg Oncol 17: 1453-1458, 2010.

21. Huang SP, Wu WJ, Chang WS, et al: p53 Codon 72 and p21 codon 31 polymorphisms in prostate cancer. Cancer Epidemiol Biomarkers Prev 13: 2217-2224, 2004.

22. Facher EA, Becich MJ, Deka A and Law JC: Association between human cancer and two polymorphisms occurring together in the p21Waf1/Cip1 cyclin-dependent kinase inhibitor gene. Cancer 79: 2424-2429, 1997.

23. Gao X, Chen YQ, Wu N, et al: Somatic mutations of the WAF1/ CIP1 gene in primary prostate cancer. Oncogene 11: 1395-1398, 1995.

24. Kibel AS, Suarez BK, Belani J, et al: CDKN1A and CDKN1B polymorphisms and risk of advanced prostate carcinoma. Cancer Res 63: 2033-2036, 2003.

25. Wang Z, Sturgis EM, Zhang F, et al: Genetic variants of p27 and $\mathrm{p} 21$ as predictors for risk of second primary malignancy in patients with index squamous cell carcinoma of head and neck. Mol Cancer 11: 17, 2012.

26. Rastinejad F and Blau HM: Genetic complementation reveals a novel regulatory role for 3' untranslated regions in growth and differentiation. Cell 72: 903-917, 1993

27. Valentin MD, Canalle R, Queiroz Rde P and Tone LG: Frequency of polymorphisms and protein expression of cyclin-dependent kinase inhibitor 1A (CDKN1A) in central nervous system tumors. Sao Paulo Med J 127: 288-294, 2009.

28. Sivonová M, Waczulíková I, Dobrota D, et al: Polymorphisms of glutathione-S-transferase M1, T1, P1 and the risk of prostate cancer: a case-control study. J Exp Clin Cancer Res 28: 32, 2009.

29. Lei D, Sturgis EM, Liu Z, Zafereo ME, Wei Q and Li G: Genetic polymorphisms of p21 and risk of second primary malignancy in patients with index squamous cell carcinoma of the head and neck. Carcinogenesis 31: 222-227, 2010.

30. Aaltomaa S, Lipponen P, Eskelinen M, Ala-Opas M and Kosma VM: Prognostic value and expression of p21(waf1/cip1) protein in prostate cancer. Prostate 39: 8-15, 1993.

31. Baretton GB, Klenk U, Diebold J, Schmeller N and Lohrs U: Proliferation and apoptosis-associated factors in advanced prostatic carcinomas before and after androgen deprivation therapy: prognostic significance of p21/WAF1/CIP1 expression. Br J Cancer 80: 546-555, 1999.

32. Omar EA, Behlouli H, Chevalier S and Aprikian AG: Relationship of p21(WAF-I) protein expression with prognosis in advanced prostate cancer treated by androgen ablation. Prostate 49: 191-199, 2001. 